Annals of Plant Sciences

\title{
Proteomic study of salt tolerant cyanobacterium Anabaena sp. BHUAR002 isolated from Usar soil
}

Aparna Rai

Department of Botany, Banaras Hindu University (BHU), Varanasi 221005, India.

Received: 2/21/2018; Revised: 2/25/2018; Accepted: 2/27/2018

\begin{abstract}
Salt stress leads to an alteration in protein profile and induction of stress-specific proteins. The SDS PAGE analysis of total soluble proteins of Anabaena sp. BHUAR002 (Accession no. bankit1353506 HM235817) exposed to $500 \mathrm{mM} \mathrm{NaCl}$ for $24 \mathrm{~h}$ revealed inhibition of host proteins, induction of selected proteins and appearance of some new proteins. In view of the appreciable alteration in total soluble protein profile after $500 \mathrm{mM}$ salt treatment for $24 \mathrm{~h}$, this dose was selected for further physiological, biochemical and proteomic analysis of the response of Anabaena sp. BHUAR002 to salinity and to examine the relationship between these responses. Further, 2DE of the total soluble protein of Anabaena sp. BHUAR002 showed 73 spots present only in control, 43 spots present only in stress and 15 differentially expressed spots present in both control and stress but show different levels of expression. This may be due to disturbance of cellular homeostasis by salt stress. Out of fifteen, Six spots were identified after MALDI-TOF MS analysis were identified as Manganese and iron Superoxide dismutase [Anabaenavariabilis ATCC 29413], Cytidine deaminase [Porphyromonas venonis 60-3], Phycobilisome Protein [Nodularia Spumigena CCY9414], DNA replication and repair protein recF [Yersinia aldovae ATCC35236], IS1112 transposase [Xanthomonas oryzae pv.oryzae PXO99A] and TP901 family phage tail tape measure protein [Xanthobacter autotrophicus Py2].
\end{abstract}

Key words: Cyanobacteria; Proteomic study; SDS - PAGE; Salt Stress, 2DE, MALDI-TOF MS

\section{Introduction}

Salinity-induced changes in physiological and biological processes ultimately lead to changes at the molecular level, which includes alteration in protein profile and gene expression. Proteins are one of the most important targets of salinity (Fulda, Huang, et al., 2000) and therefore their degradation synergizes the deleterious effect of salt stress. Identification of a protein from genomic database search has been done by excision of protein spot from control and treated 2D gel and obtained peptide ion mass list by MALDI-TOF MS (Figure1).

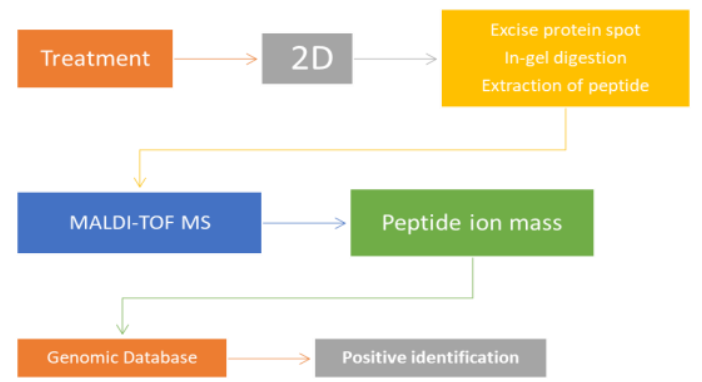

Figure 1: The Use of Proteomics to Study Osmotic Stress.

However, another way to stress reflection and tolerance offered by cyanobacteria is a change in protein profile. Different workers have been study the proteome for better understanding of stress

\footnotetext{
*Corresponding Author:

Aparna Rai,

Department of Botany,

Banaras Hindu University (BHU),

Varanasi 221005, India.

E-mail: aparna.rai82@gmail.com
}

response (Duché, Trémoulet, et al., 2002, EhlingSchulz, Schulz, et al., 2002, Ferianc, Farewell, et al., 1998, Fulda, Huang, et al., 2000, Fulda, Huckauf, et al., 1999) because the fold up-regulation of genes are not always in tune with the respective gene products i.e. proteins, which are actually involved in stress tolerance (Yan, Tang, et al., 2005). Therefore, proteomic has become a promising and complementary tool in the post-genomic era.

In addition to above, functional gene expression can only be achieved by proteomic analysis and also shows the stress-induced post-translational modifications (Parker, Flowers, et al., 2006). Genome sequencing followed by proteome analysis using two-dimensional gel electrophoresis combined with micro-sequencing to characterize expressed protein is the basic for proteomics. With the use of these techniques, a large number of proteins have so far been identified in cyanobacteria (Sazuka, Yamaguchi, et al., 1999).

Salinity causes three types of changes in protein profile that is an expression of a group of proteins, disappearance or suppression of another group of proteins, and expression of a new set of proteins, commonly known as salt-responsive proteins (Apte and Bhagwat, 1989). Cyanobacteria under salinity stress induced an important protein ubiquitin (Durner and Böger, 1995) it has an important role in cellular housekeeping because it provides an ATP

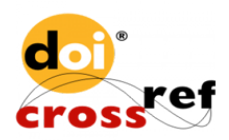


dependent proteolytic mechanisms that specifically degrades abnormal proteins. Protease is also involved in degradation of abnormal proteins to release amino acids for their re-utilization during protein synthesis. This concept is termed as "Proteolysis of Secondary Antioxidant Defence" (Grune, Blasig, et al., 1998).

Proteins which respond to salt stress are of two types, general stress proteins, and salt stress specific proteins. Dna K or Hsp 70 (Fulda, Huckauf, et al., 1999) are general stress protein which can respond to any stress condition and Gro EL or Hsp 60 (Vinnemeier, Kunert, et al., 1998) have been reported to be induced in response to salt stress. Studies of stress-responsive proteins have been done by different researchers (Acea, PrietoFernandez, et al., 2003, Apte and Bhagwat, 1989, Fulda, Huang, et al., 2000).

\section{Materials and Methods}

The technique of PAGE using a discontinuous buffer system was introduced to improve the resolution of the separated protein bands and the concentration of samples (Davis, 1964, Ornstein, 1964). PAGE was adopted for use with the detergent sodium dodecyl sulfate (SDS) (Laemmli, 1970). When denatured by heating in the presence of excess SDS and a thiol reagent (dithiothreitol), most proteins bind the detergent in a constant ratio of $1.4 \mathrm{~g} / \mathrm{g}$ protein. Under this condition, the detergent introduces -ve charges which nullify the intrinsic charges of the protein thus, migration of polypeptides in SDS - PAGE largely depends upon size rather than charge (Weber and Osborn, 1969).

In order to see the effect of salt $(\mathrm{NaCl})$ on protein profile of Anabaena sp. BHUAR002 (Accession no. bankit1353506 HM235817) (Rai and Rai, 2011) the cells were grown with different concentrations of salts $(\mathrm{NaCl})$ and protein samples were prepared by following modified method (Wagner, Eschenbrenner, et al., 2002).

\section{Preparation of protein sample}

Protein extraction was performed using a modified protocol of Wagner et al., (Wagner, Eschenbrenner, et al., 2002). $\mathrm{NaCl}$ treated $(500 \mathrm{mM}, 24 \mathrm{~h}$ incubation) Anabaena sp. BHUAR002 cells harvested by centrifugation were washed with Tris buffer ( $\mathrm{pH}$ 8.0) and suspended in $5 \mathrm{ml}$ extraction buffer. Cells were ground under liquid nitrogen followed by centrifugation at 10,000 rpm for $1 \mathrm{~h}$. The supernatant so obtained was treated with $10 \%$ TCA in acetone, incubated overnight at $-20^{\circ} \mathrm{C}$ to ensure complete protein precipitation and centrifugation at $8,000 \mathrm{rpm}$ for $15 \mathrm{~min}$ to recover protein pellet. Additional washing with acetone was done to remove TCA. The pellet was air dried and suspended in sample loading buffer specific for SDS-PAGE and 2DE.

\section{SDS-PAGE}

Running gel was prepared by using the $15 \%$ resolving gel poured $2 / 3$ part of the plate and top level was made smooth and straight by adding about $2 \mathrm{ml}$ of $50 \%(\mathrm{v} / \mathrm{v})$ methanol solution after settling the gel methanol layer was removed and washed with sterilized DDW then staking gel was poured on running gel and wells were made in the stacking gel by inserting comb. After satisfactory polymerization of the gel, comb was removed and the Tris-glycine electrophoresis buffer (running buffer) was used to fill the space sample compartment. The upper and lower buffer tanks were finally filled by electrophoresis (Running) buffer. The protein sample $20 \mu \mathrm{g}$ standard protein marker ranging from 3000 - 205000 Da were loaded simultaneously in the wells. The solutions were heat treated for $10 \mathrm{~min}$ at $100^{\circ} \mathrm{C}$ in boiling water bath prior to loading of the samples.

The slab gel electrophoresis was carried out at $4^{\circ} \mathrm{C}$ using a current of $\mathrm{mA}$ with $100 \mathrm{~V}$ for stacking and $150 \mathrm{~V}$ for resolving. The gel was removed when tracking dye reached to its bottom and the bromophenol blue dye was not allowed to run out of the gel. The gel was stained for overnight in the staining solution prepared by using coomassie brilliant blue R-250 (Sigma grade) and the gel was destained by flooding it with destainer after a regular time interval, the destaining solution (methanol, acetic acid solution) was replaced by the freshly prepared destaining solution. This process was repeated till the background of the gel become clear and protein bands were clearly visible to naked eye.

\section{D Gel Electrophoresis}

Two-dimensional gel electrophoresis is commonly used to analyze proteins are separated by two properties in two dimensions on the $2 \mathrm{D}$ gel.

\section{First dimension}

This includes the steps of Rehydration and Isoelectric Focusing.

Rehydration: The sample was prepared in rehydration buffer. Pipette out $300 \mu \mathrm{l}$ volume of sample as a line along the back edge of a channel in a rehydration/equilibration tray. Biorad IPG strip $(17 \mathrm{~cm})$ was taken out and strip out the plastic leaf over it carefully. Strip was placed in the rehydration/equilibration tray lane over the sample so that its gel side touches rehydration buffer solution and the pointed end towards the slope of the tray. Overlay the strip with 2 to $3 \mathrm{ml}$ of mineral oil to prevent evaporation during the rehydration process. Rehydration/equilibration tray was cover with the plastic lid and the tray was kept sitting on a level bench overnight (11-16 h) to rehydrate the IPG strip. 
Isoelectric focusing: A clean, dry PROTEAN ${ }^{\circledR}$ IEF focusing tray was placed onto the lab bench. Using forceps, a paper wick was placed at both the ends of the channels covering the wire electrodes. Pipette out $8 \mu$ of sterilized DDW onto each wick to wet them. The cover removed from the rehydration/equilibration tray containing the IPG strip. Using forceps, carefully hold the strip vertically for about 7 to $8 \mathrm{sec}$ and tip of the strip was bloated on a piece of filter paper to allow the mineral oil to drain, then transferred the IPG strip to the corresponding channel in the focusing tray (maintain the gel side down). Remember to observe the correct polarity during the transfer. The "+" marked on the strip should be positioned at the end of the tray also marked "+".Each IPG strip was covered with 2 to $3 \mathrm{ml}$ of fresh mineral oil. Check and remove if any trapped air bubbles beneath the strip. The lid was placed on the tray. The focusing tray was placed into the PROTEAN IEF cell and the cover was closed.

\section{PROTEAN IEF cell using following protocol} 17cm (IEF STRIP): Step 1: 500V, linear, 01:00h, Step 2: 1000V, linear, 01:00h Step 3: 10,000V, linear, 04:00h, Step 4: 10,000V, rapid, and 50,000Vh, Step 5: 500V, slow, 24:00h. It started to initiate the electrophoresis run. The strip may be kept at $-80{ }^{\circ} \mathrm{C}$ for overnight use.

\section{Second dimension}

Equilibration and SDS run are the part of second dimensions

Equilibration: Removed the mineral oil from the ready strip IPG strip by placing the strip (gel side up) onto a piece of dry filter paper and blotting with a second piece of wet filter paper. Added $5 \mathrm{ml}$ of equilibration buffer 1 with DT'T to an equilibration/rehydration tray, transfer the blotted ready strip IPG strip (gel side up) to the equilibration tray. Place the tray on a rocker shaker and gently shake for $10 \mathrm{~min}$. After placing the IPG strips on the shaker in equilibration buffer 1 with DTT, Proceed to complete the preparation of equilibration buffer-2 with iodoacetamide. At the end of the $10 \mathrm{~min}$ incubation, discard the used equilibration buffer by carefully decanting the liquid from the tray. Add $5 \mathrm{~mL}$ of equilibration buffer 2 with iodoacetamide to the strip. Return the tray to the rocker shaker for $10 \mathrm{~min}$. Discard the equilibration buffer 2 with iodoacetamide by decanting at the end of the incubation period and drain the moisture from the equilibration strip by soothing them over a filter paper.

SDS Run: Prepared a resolving gel solution of $12 \%$ and pour it in between the plates of the cassette and let it be polymerized for 30-40 min. gel layer was filled with (milli Q) water immediately to make sure it settles evenly and prevented from air contact. Stacking gel solution was prepared and poured over the polymerized resolving gel in the cassette and let it be polymerized for $\sim 15 \mathrm{~min}$. Dip the strip in the SDS electrophoresis buffer to lubricate it. Place it in between the two glass plates of the cassette. Push it down with the help of a ruler ensuring no air bubbles in between. Seal the top of the plates with agar sealing solution. Care should be taken ensuring no air bubbles in between. Fill the tank with electrophoresis buffer and place the gel cassette in the $2 \mathrm{D}$ gel running assembly. Run the gel at $16 \mathrm{~mA}$ for $15 \mathrm{~min}$. and then $25 \mathrm{~mA}$ at till the dye reaches the bottom of the gel.

\section{Spot Cutting and Tryptic Digestion of Proteins for Protein Identification}

Rinse gel 2 times for $10 \mathrm{~min}$ in MQ water. Transfer gel to alcohol wiped transparency and cut the spot/band of interest using a clean scalpel or razor blade. Transfer the gel plugs into clean Eppendorf tubes.

Silver-stained gel pieces were once washed with HPLC water and washed twice with destaining solution I (15mM potassium ferricyanide / 50mM sodium thiosulphate) for 10-15 minutes with a continuous vortexing. Gel pieces were washed twice with HPLC water for 10-20 min. Gel pieces were washed with destaining solution II $(50 \% 100 \mathrm{mM}$ $\mathrm{NH} 4 \mathrm{HCO} 3 / 50 \% \mathrm{CAN}$ ) for 5 minutes. Coomassiestained gel pieces were covered with a destaining solution II and incubated at $37^{\circ} \mathrm{C}$ for $30 \mathrm{~min}$. The solution was removed and discarded from the tube. The above steps were repeated twice till stain is completely removed and gel pieces were clear. Shrink or dehydrate gel pieces by adding acetonitrile and incubate samples for $5 \mathrm{~min}$ at room temperature. Removed the acetonitrile and allowed the gel pieces to air-dry for $5 \mathrm{~min}$. Reduction solution (10mM DTT in $100 \mathrm{mM}$ NH4HCO3) was added to the tubes containing gel pieces and incubated at $56^{\circ} \mathrm{C}$ for $30 \mathrm{~min}$. Kept the tubes at room temperature for $5 \mathrm{~min}$ and discarded the reduction solution. Added alkylation buffer $(50 \mathrm{mM}$ iodoacetamide in $10 \mathrm{mM}$ of NH4HCO3) to the gel pieces and incubate the sample in dark at room temperature for $30 \mathrm{~min}$. Removed and discarded alkylation buffer from the tube Wash the gel pieces by adding destaining solution-I to the tube. Vortex for $10 \mathrm{~min}$ and repeated the above step once more. Shrinked gel pieces by adding acetonitrile and samples were incubated for $5 \mathrm{~min}$ at room temperature (RT). Removed acetonitrile and allowed gel pieces to air-dry for $5 \mathrm{~min}$. Swelled gel pieces by adding $20 \mathrm{ng} / \mu \mathrm{l}$ of trypsin solution to the tube depending on the size of gel piece. Sample Incubated at RT for $10 \mathrm{~min}$ and allowed the gel pieces to swell and absorbed the trypsin solution and incubated the tube at $37^{\circ} \mathrm{C}$ for $16 \mathrm{~h}$. To extract the peptides after the overnight incubation peptide extraction solution (1\% TFA in ultra-pure water) was added depending upon the gel volume. The tubes were sonicated in a water bath sonicator for 5 minutes. 


\section{Protocol for MALDI - TOF MS}

Samples for MALDI-TOF analysis were prepared using dried droplet method. $1 \mu$ peptide solution (peptide extracts after tryptic digestion) and $1 \mu \mathrm{l}$ of a suitable matrix, e.g. alpha-cyano hydroxycinnamic acid (HCCA) in 1:2 v/v of Acetonitrile (ACN):0.1 $\%$ TFA were mixed nicely. $1 \mu \mathrm{l}$ of this mixture was spotted on a MALDI target plate and allowed to air dry at room temperature (RT). Peptide calibration standard (BRUKER) was also prepared in the same way. MALDI target plate was loaded into Ultraflex MALDI-TOF for subsequent peptide spectra acquisition and analysis. A LASER power of 337 $\mathrm{nm}$ wavelength was used for ionization of the samples spotted on the target plate. Peptide peaks were calibrated with peaks obtained from the peptide calibration standard. After peptide spectra's were obtained, MS analysis was carried out using Flex analysis software ( $\mathrm{v}$ 2.2, BRUKER). Subsequent MS data analysis was carried out using Biotools software (v 2.2, BRUKER) and MASCOT search engine (Matrix Science) against the NCBI database.

\section{Results}

The proteomic analysis contains the result of onedimensional gel electrophoresis (SDS-PAGE), twodimensional gel electrophoresis and identification and characterization of proteins by MALDI-TOF MS. As earlier described extraction and estimation of protein, the amount of protein in control and stressed (500mM NaCl, at $24 \mathrm{~h}$ of incubation) Anabaena sp. BHUAR002 was found to be $260-\mu \mathrm{g}$ $\mathrm{ml}^{-1}$ and $240 \mu \mathrm{g} \mathrm{ml}^{-1}$ respectively.

SDS-PAGE of extracted protein was run, different bands were found in control as well as stressed protein extract (Figure-2). These bands were analyzed by comparing with a wide range of marker protein (3000-205,000 Da). Many bands were found in control as well as stressed protein samples. On viewing the band pattern from high to low molecular weight, it was found that a band in both control and stress protein sample corresponding to $205000 \mathrm{Da}$ of the marker protein. A band in control was found between 97400 and $205000 \mathrm{Da}$ but near to $205000 \mathrm{Da}$ and a band also seen in stress protein sample just little more molecular weight than 97400 Da nearly $66000 \mathrm{Da}$ molecular weight protein is also found in both control and stress protein sample. Between 66000 and $43000 \mathrm{Da}$ molecular weight band was found both in control and stress protein extract of Anabaena sp. BHUAR002. One band that present in control and stress both lies between 29000 and 20100 molecular weight and another band was found in both control and stress protein and lie between 43000 and 29000 molecular weight. 6500 molecular weight band was found in stress protein. A band in control sample lay between 6500 and 14300 Da molecular weight. It was found that a band in the stressed sample was very close to $3000 \mathrm{Da}$ but not exactly $3000 \mathrm{Da}$ stressed sample was very close to $3000 \mathrm{Da}$ but not exactly $3000 \mathrm{Da}$ slightly higher in molecular weight than the $3000 \mathrm{Da}$.

2D Electrophoresis was performed to investigate effects of salt stress ( $\mathrm{NaCl}$ stress) on the total soluble protein of Anabaena sp. BHUAR002. A comparison of control and $\mathrm{NaCl}$ treated Anabaena sp. BHUAR002 is shown in Figure-3. A total of 58 (1-43 and a-O) and 43 (44-71 and a-o) spots were clearly visible in control, and $\mathrm{NaCl}$ treated cells, respectively (Figures. 3 and 4). Out of the 58 spots in control (as revealed by PD Quest software) 15 proteins spots were found to be common to $\mathrm{NaCl}$ treated cells (Fig. 4). 15 Protein spots with altered intensity were picked up from various $2 \mathrm{DE}$ gels and identified by MALDI-TOF-MS. Results obtained for 6 spots shown in Figure 5. Details of these proteins are given in Table 1.

Table 1. Identification of $\mathrm{NaCl}$ responsive proteins in Anabaena sp. BHUAR002

\begin{tabular}{|c|c|c|c|c|c|c|}
\hline Spots & $\begin{array}{l}\text { Homologous protein } \\
\text { (showing homology with) }\end{array}$ & $\begin{array}{l}\text { Probability- } \\
\text { based } \\
\text { Mowse score }\end{array}$ & $\underset{(\mathrm{kDa})}{\mathrm{Mr}}$ & PI & $\begin{array}{l}\text { Accession } \\
\text { Number }\end{array}$ & $\begin{array}{l}\text { Protein } \\
\text { Expressed under } \\
\text { salt stress }\end{array}$ \\
\hline D & $\begin{array}{l}\text { DNA replication and repair } \\
\text { protien recF [Yersiniaaldovae } \\
\text { ATCC35236] }\end{array}$ & 85 & 40.8 & 9.8 & ZP04620748 & $(-)$ \\
\hline & IS1112 transposase & & & & & \\
\hline $\mathbf{E}$ & $\begin{array}{l}\text { Xanthomonas oryzae pv.oryzae } \\
\text { PXO99A] }\end{array}$ & 85 & 31.0 & 12.4 & YP001913347 & $(-)$ \\
\hline I & $\begin{array}{l}\text { TP901 family phage tail tape } \\
\text { measure protein [Xanthobacter } \\
\text { autotrophicus } \mathrm{Py} 2 \text { ] }\end{array}$ & 89 & 69.6 & 6.2 & YP001419365 & $(-)$ \\
\hline $\mathbf{L}$ & $\begin{array}{l}\text { Manganese and iron Superoxide } \\
\text { dismutase [Anabaenavariabilis } \\
\text { ATCC 29413] }\end{array}$ & 86 & 22.4 & 5.2 & YP321482 & $(+)$ \\
\hline $\mathbf{N}$ & $\begin{array}{l}\text { Cytidine deaminase } \\
\text { [Porphyromonas venonis } 60-3 \text { ] }\end{array}$ & 84 & 17.7 & 4.9 & ZP04055740 & $(+)$ \\
\hline $\mathbf{O}$ & $\begin{array}{l}\text { Phycobilisome Protein } \\
\text { [Nodularia Spumigena CCY9414] }\end{array}$ & 124 & 17.4 & 4.8 & ZP01629883 & $(+)$ \\
\hline
\end{tabular}




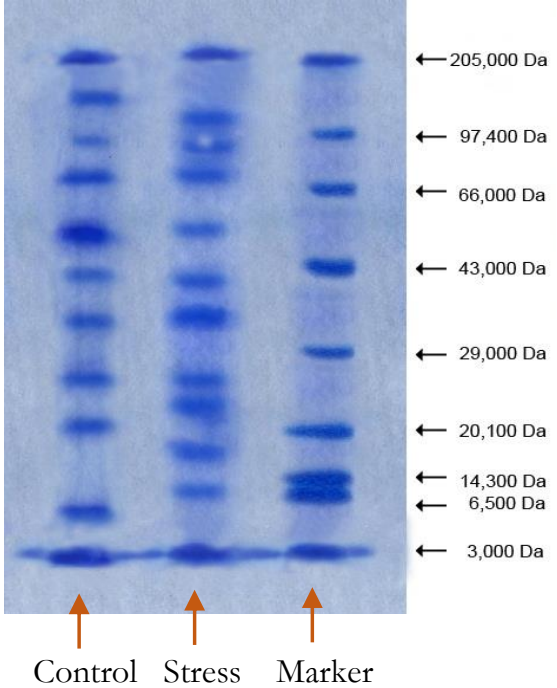

Figure 2. Band pattern of whole cell protein in stressed (500 mM NaCl, $24 \mathrm{~h}$ of incubation) and control sample of Anabaena sp. BHUAR002.

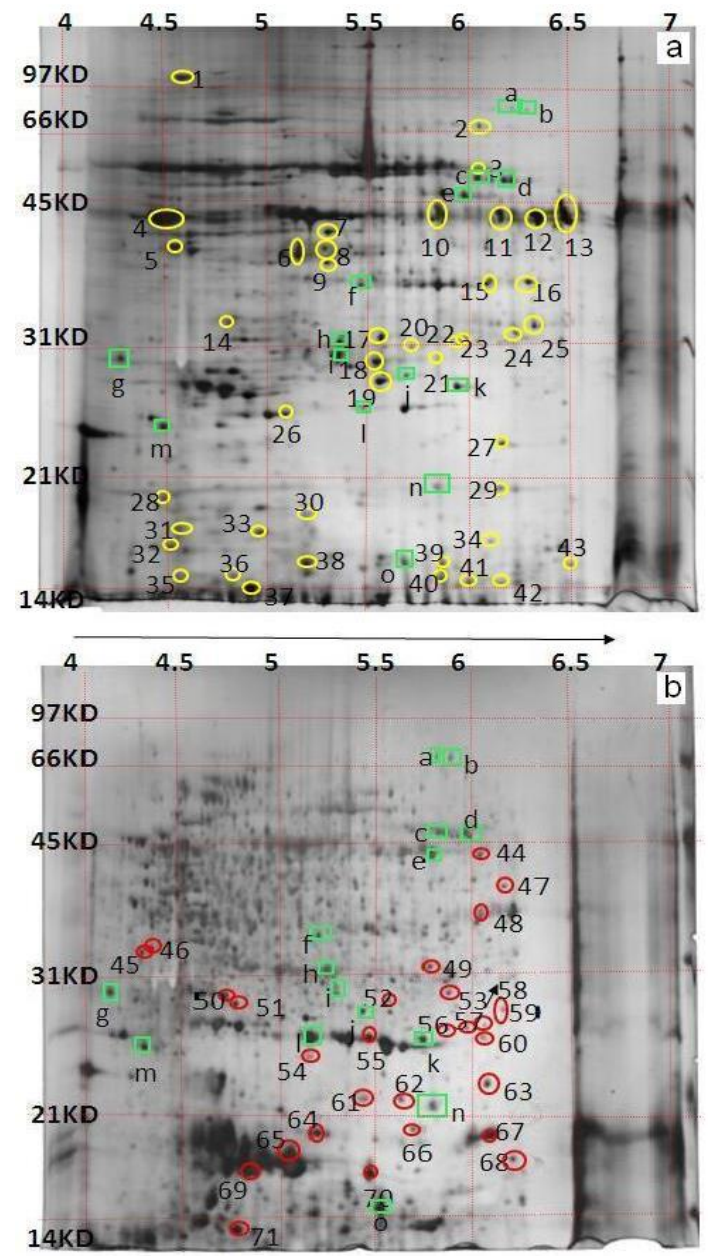

Figure 3. Two-dimensional gel electrophoretic images of the total soluble protein of Anabaena sp. BHUAR002: (a) control, (b) exposed to $500 \mathrm{mM}$ $\mathrm{NaCl}$, six differentially expressed proteins were identify by MALDI-TOF MS. (1-43 spots (Yellow) present only in control, 44-71 spots (Red) present only in treated cell, and spots a-o, (Green) are differentially expressed spots present in both control and treated cells).

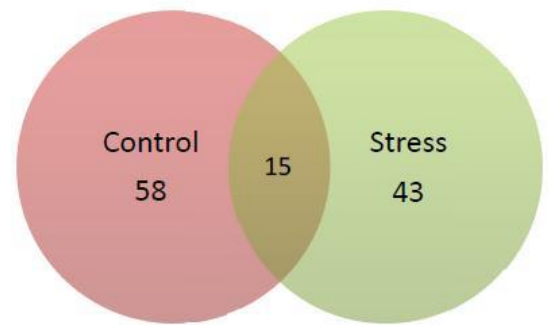

Figure 4. Venn diagram representation of different sets and subset of proteins found from twodimensional gel electrophoresis of Anabaena sp. BHUAR002

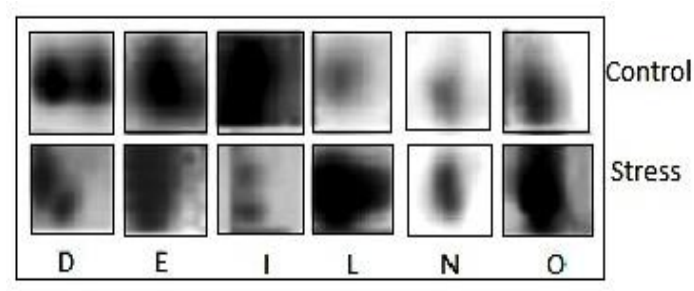

Figure 5. Changes in protein abundance due to $\mathrm{NaCl}$ treatment in Anabaena sp. BHUAR002 exposed to $500 \mathrm{mM} \mathrm{NaCl}$. The protein was extracted and separated by $2 \mathrm{DE}$

\section{Discussion}

Despite above, long-term survival (i.e. growth) requires the development of the protein synthesisdependent adaptive state, which is usually reached approximately after the equivalent of one generation time (Hagemann, Wolfel, et al., 1990). The study of an investigation of the effect of salinity on proteins because an alteration in various physiological and biochemical processes results in change in protein expression (Yan, Tang, et al., 2005).

Inhibition of RNA and proteins may be due to the inhibition of different steps of their biosynthesis and oxidative modification by $\mathrm{NaCl}$ stress (Cabiscol, Tamarit, et al., 2000, Chen and Zhu, 2004). Either reduction in some protein content or induction in other proteins or appearance of a set of new proteins was observed in the SDS-PAGE analysis of total proteins of Anabaena sp. BHUAR002 under control and salt stress $(500 \mathrm{mM}$ $\mathrm{NaCl}$ ) (Figure 2) This analysis showed a significant salt shock may be attributed to the sensitivity of the transcription and translation of these proteins (Vogel, Parsell, et al., 1995) and represents a salt adaptive response.

For a better understanding of salinity-induced proteome, 2DE of the total soluble protein of Anabaena sp. BHUAR002 under salt stress was observed (Figure 3). A significant reduction in protein spots in control and stressed cells was 
observed. Different workers have been reported that salinity induced reactive oxygen species production, which attacks the side chains of amino acids in a polypeptide (Stadtman, 1993) and activation of proteases which degrade the protein (Ning, Guo, et al., 2002) are possible reasons for change for a change in protein level. 15 spots of a protein selected for MALDI-TOF MS analysis after $2 \mathrm{DE}$ are differentially expressed spots. Out of 15 , six proteins were identified by MALDI-TOF MS.

The disruption of protein synthesis appears to be the important cause of damage by $\mathrm{Na}^{+}$(Tester and Davenport, 2003). Inhibition of protein contents may be due to the inhibition of different steps of their biosynthesis and oxidative damage.

\section{References}

1. Acea MJ, Prieto-Fernandez A, \& Diz-Cid, N. "Cyanobacterial inoculation of heated soils: effect on microorganisms of $\mathrm{C}$ and $\mathrm{N}$ cycles and on chemical composition in soil surface." Soil. Biol. Biochem 35 (2003): 513-524.

2. Apte SK and Bhagwat AA. "Salinity-stressinduced proteins in two nitrogen-fixing Anabaena strains differentially tolerant to salt.” J. Bacteriol 171(1989): 909-915.

3. Cabiscol E, Tamarit J and Ros J. "Oxidative stress in bacteria and protein damage by reactive oxygen species." Internatl. Microbiol 3 (2000): 3-8.

4. Chen WJ and Zhu T. "Networks of transcription factors with roles in environmental stress response." Trends Plant Sci 9(2004): 591-596.

5. Davis BJ. "Disc Electrophoresis 2, method and application to human serum proteins." Ann. New York Acad. Sci 121(1964): 404427.

6. Duché O, Trémoulet $\mathrm{F}$ and Namane A. "The European Listeria Genome Consortium and Labadie J. A proteomic analysis of salt stress response of Listeria monocytogenes." FEMS Microbiol Let 215(2002): 183-188.

7. Durner J and Böger P. "Ubiquitin in prokaryote Anabaena variabilis." J. Biol. Chem 270(1995). :3720-3725.

8. Ehling-Schulz M, Schulz S, Wait R, Gorg A, and Scherer S. "The UV-B stimulon of the terrestrial cyanobacterium Nostoc commune comprises early shock proteins and late acclimation proteins." Mol. Microbiol 46(2002): 827-843.
9. Ferianc P, Farewell A, and Nystrom T. "The cadmium-stress stimulon of Escherichia coli K-12.” Microbiology 144(1998): 1045-1050.

10. Fulda S, Huang F, Nilsson F, Hagemann M and Norling B. "Proteomics of Synechocystis sp. strain PCC 6803 identification of periplasmic proteins in cells grown at low and high salt concentrations." Eur. J. Biochem 267(2000): 5900-5907.

11. Fulda S, Huckauf J, Schoor A, and Hagemann M. "Analysis of stress responses in the cyanobacterial strains Synechococcus sp. PCC 7942, Synechocystis sp. PCC 6803, and Synechococcus sp. PCC 7418: osmolyte accumulation and stress protein synthesis." J Plant Physiol 154(1999): 240-249.

12. Grune T, Blasig IE, Sitte N, Roloff B, Haseloff R, and Davies KJA. "Peroxynitrite increases the degradation of aconitase and other cellular proteins by proteasome." J. Biol. Chem 273 (1998): 857-862.

13. Hagemann M, Wolfel L, and Kruger B. "Alterations of protein synthesis in the cyanobacterium Synechocystis sp. PCC 6803 after a salt shock." J. Gen. Microbiol 136(1990): 1393-1399.

14. Laemmli UK. "Cleavage of structural proteins during the assembly of the head of bacteriophage T4." Nature 227(1970): 680685.

15. Ning SB, Guo HL, Wang L, and Song YC. "Salt stress induced programmed cell death in prokaryotic organism Anabaena." J. Appl. Microbiol 93 (2002): 15-28.

16. Ornstein L. "Disc Electrophoresis 1, background and theory." Ann. New York Acad. Sci 121 (1964): 321-349.

17. Parker R, Flowers TJ, Moor AL, and Harphan NVJ. "An accurate and reproducible method for proteome profiling of the effects of stress in rice leaf lamina." J. Exp. Bot 57 (2006): 1109-1118.

18. Rai A and Rai AK. "Morphological and molecular characterization of two usar soil cyanobacterial isolates." Journal of Scientific and Applied Research 2(2011): 136 - 141.

19. Sazuka T, Yamaguchi M, and Ohara O. "Cyano2 base updated: linkage of 234 protein spots to corresponding genes through $\mathrm{N}$ terminal microsequencing." Electrophoresis 20(1999): 2160-2171. 
20. Stadtman ER. "Oxidation of free amino acids and amino acid residues in proteins by radiolysis and by metal-catalyzed reactions." Ann. Rev. Biochem 62 (1993): 797-821.

21. Tester M, and Davenport R. "Na+ tolerance and $\mathrm{Na}+$ transport in higher plants." Ann. Bot 91 (2003), 503-527.

22. Vinnemeier J, Kunert A, and Hagemann M. "Transcriptional analysis of the isiAB operon in salt-stressed cells of the cyanobacterium Synechocystis sp. PCC 6803." FEMS Microbiol. Lett 169 (1998): 323-330.

23. Vogel JL, Parsell DA, and Lindquist S. "Heatshock proteins Hsp104 and Hsp70 reactivate mRNA splicing after heat inactivation. Curr. Biol 5 (1995): 306-317.

24. Wagner MA, Eschenbrenner M, Horn TA, Kraycer JA, Mujer CV, Hagius S, et al.
"Global analysis of the Brucella melitensis proteome: Identification of proteins expressed in laboratory-grown culture." Proteomics, 2(2002): 1047-1060.

25. Weber K and Osborn M. "The Reliability of Molecular Weight Determinations by Dodecyl Sulfate-Polyacrylamide Gel Electrophoresis." J. Biol. Chem 244 (1969): 4406-4412.

26. Yan S, Tang Z, Su W, and Sun W. "Proteomic analysis of salt stress-responsive proteins in rice root.” Proteomics 5 (2005): 235-244.

\section{Cite this article as:}

Aparna Rai. Proteomic study of salt tolerant cyanobacterium Anabaena sp. BHUAR002 isolated from Usar soil. Annals of Plant Sciences 7.3 (2018) pp. 2154-2160.

do $\mathrm{http://dx.doi.org/10.21746/aps.2018.7.3.11}$ 